\title{
WORK ANOMIE IN AN ORGANISATION
}

\author{
Barbara A. Sypniewska*
}

\begin{abstract}
Background. Anomie at work is a type of social anomie interrelated with professional activities that entail employees being exposed to repeated temptations. Under such conditions they come up with credible justifications that become fixed. Anomie manifests itself in organisations where there are values that have even been written down, but they are not held on to. One should seek the sources of anomie in the organisational culture, organisational structure, organisation of work, motivation and management methods, legal rules as well as in human behaviours and value systems, and in the mechanisms regulating social behaviours in an organisation. The phenomenon of anomie at work is part of the nature of any business, but every ethical act limits it. The objective of this paper is to analyse anomie at work, the conditioning and causes of this phenomenon, and methods of dealing with anomie at work.
\end{abstract}

Research aims. The objective of this paper is to analyse anomie at work, the conditioning and causes of this phenomenon, and methods of dealing with anomie at work, taking into account the problem of temptation as well as to analyse the dissonance between one's dignity and the inner justifications one uses, that is, excuses for improper conduct. The article presents the findings of own study carried out in 2017 on a group of 1,027 respondents. The analysis aims at identifying anomic behaviours and excuses offered to justify them, that is, explanations for inappropriate and unethical conduct. Simultaneously, the study is an attempt at verification of a thesis that the phenomenon of anomie at work is present in organisations regardless of the type of company activity, capital, and size, but it is dependent on gender, age, education, form of employment, and position.

Methodology. In the first quarter of 2017, a questionnaire-based quantitative study was carried out with the use of survey questionnaires on a group of 1,027 people. The respondents were selected by way of purposive sampling. The selection criterion was employment in a company operating in Poland, regardless of company size. Self-employed persons were excluded from the study.

Key findings. Based on the study, it may be claimed that the phenomenon of anomie at work is present in organisations and manifests itself in the form of different anomic behaviours. Similarly, there is a variety of justifications/excuses for one's anomic behaviours, which serve as a basis for internal reinterpretation. The study

\footnotetext{
University of Finance and Management in Warsaw. Email: agata.sypni@op.pl
} 
demonstrated that the phenomenon of anomie at work is present in organisations regardless of the type of company activity, capital, and size, but it is dependent on gender, age, education, form of employment, and position.

Keywords: anomie at work, temptation, justifications, dignity dissonance.

\section{INTRODUCTION}

In the current (economic and social) reality, organisations remain under the influence of both external (environmental) and internal (organisational) factors. Companies are liable to dysfunction, aberrations, pathologies, etc. - which are all deviations from the accepted norms and values (Baumer, 2007; Featherstone \& Deflem, 2003). One of such deviations is anomie, which in order to be identified and counteracted requires placing emphasis on working out the personal ethos of a superior and a culture based on ethical conduct (Cohen, 1992a 1992b; Passas, 1990; Vaughan, 1983; Zahra, 1989). The culture focuses on values, beliefs, and expectations of its members (Hatch, 2002) who share, among others, norms, values, and beliefs that should be preserved; this is expressed by work ethic (Sudoł, 2006). According to J. Kisielnicki (2008), work ethos is a set of virtues that determines the degree of braveness displayed by business people. Whereas, G. Morgan (1997) believes that values held by an organisation encourage employees to show enthusiasm and share the ethos of addressing problems and ideas jointly. The phenomenon of anomie at work is part of the nature of any business, but every ethical act limits it. Anomie manifests itself in organisations where there are values that have even been written down, but they are not held on to. It emerges where improper management style is in place and employees are not treated as individual human beings. Innovation in management comes down to managers adhering to widely recognised norms and values and treating employees with respect and equitably. The objective of this paper is to analyse anomie at work, the conditioning and causes of this phenomenon, and methods of dealing with it, taking into account temptation, as well as to analyse the dissonance between one's dignity and the inner justifications for improper conduct. The article presents the findings of own study carried out in 2017 on a group of 1,027 respondents. The analysis aims at identifying anomic behaviours and excuses offered to justify them, that is, explanations for inappropriate and unethical 
conduct. Simultaneously, the study attempts to verify a thesis that the phenomenon of anomie at work is present in organisations regardless of the type of company activity, capital, and size, but it is dependent on gender, age, education, form of employment, and position. Based on the study, it may be claimed that the phenomenon of anomie at work is present in organisations, but manifests itself in the form of different anomic behaviours depending on the type of temptation. Similarly, there is a variety of justifications/excuses for one's anomic behaviours, which serve as basis for internal reinterpretation.

\section{ANOMIE}

The term anomie (from Greek a-without; nomos-law) is derived from social studies (sociology and psychology) (Poveda, 1994). The phenomenon is related to two traditions of scientific thinking. The first one is the theory of Émile Durkheim from the turn of the $19^{\text {th }}$ and $20^{\text {th }}$ century and the second one was initiated in 1938 by Robert Merton. The two understandings were completely dissimilar although there is a lot of similarity between them in terms of non-observance of the norms and interpretation of social behaviours. Anomie, as described by E. Durkheim, is a state arising from the lack of regulation and misalignment between the rules and the order that is being formed. The author analysed the frequency of suicides occurring shortly after a crisis or improvement of social welfare (Durkheim, 2006, pp. 305-323; Durkheim, 2000, pp. 37-66; McCloskey, 1976, pp. 1481-1487; Willis, 1982, pp. 106-113). The point of departure is an individual's conviction about the irresistible urge to satisfy greater and greater desires. Happiness is dependent on the attainment of goals, regardless of the available resources. Discomfort arises when the individual wishes to achieve more than they are capable of, which causes the desire to live to weaken and aspiration to disappear owing to a chronic mismatch between one's expectations and opportunities. Anomie occurs when individuals forming a society lose the ability to tell good from evil, which may be indicative of a social crisis. Anomie is also a decline of prevailing social norms and creation of other ones which are not always accepted and often imposed by force, lawlessness, ambiguity of situation, or uncertainty (Stelmach, 2009, p. 19). Anomie may be present in societies, communities, and certain groups. 
In his deliberations on anomie, R. Merton discerned two elements determining actions: the goal the society pursues and the manner of attaining it (Merton, 2002, pp. 197-204; Merton, 1938, pp. 672-682; Thio, 1975, pp. 139-158; Messner, 2003). The goals are a set of aspirations pertaining to the hierarchy of values and trigger engagement and emotions. Possibilities offer opportunities to "take a shortcut". In some societies, what matters is effectiveness and practical efficiency, while the means of pursuing one's goals are unimportant. Then behaviours become perverted. Such a situation leads to anomie which is understood as the lack of norms. The process where the goal comes before the method leads to pathology. The line between good and evil becomes blurred and norms - unclear. The relationship between values and acceptable manners of behaviour may take various forms: conformism, retreatism, rebellion, innovation, and ritualism. Rebellion and retreatism lead to rejection of values and social behaviours (Szacka, 2008, pp. 171-178). Merton discerned two forms of anomie: normal and acute. Normal refers to confrontation between systems of values and conflict within a group's values, which cause anxiety; whereas acute anomie in the most extreme cases leads to a breakdown of the systems of values, which causes violent anxiety states (Merton, 2002, p. 227).

Anomie is a discord between the acceptable purposes of action (i.e., values) and the means of pursuing them. When there is anomie, there is no adjustment between the socially acceptable purposes of action and possible or (legitimate) means of accomplishment of those purposes (Szafraniec, 1986; Sztompke, 2007; Szczepański, 1963). It may be assumed that social anomie is the state of society where social norms and values exist, but are not respected. According to M. Kosewski (2008), social anomie is an arrangement consisting in the society agreeing about excuses to be used, if certain temptation arises. A subculture of excuses emerges, which serves a certain function when tempting situations reappear. High credibility of excuses that the society agreed upon causes group members to be convinced about the rightfulness of such behaviours. M. Kosewski also distinguishes personal anomie - a personal capability of reducing the dignity dissonances when temptations arise (Kosewski, 2008, p. 37).

One may seek the causes of anomie in violent and dominant social changes, political changes, rapid economic development, wars, or revolutions (Tyc, 2007, p. 267; Turska-Kawa, 2010, pp. 102-107). 


\section{ANOMIE AT WORK}

Anomie at work is a type of social anomie interrelated with professional activities that entail employees being exposed to repeated temptations. Under such conditions they come up with credible justifications that become fixed. Anomie at work is the lack of adherence to norms. Employees may assume that what is currently accepted in an organisation is not right and acts against their interest and thus remain anomic, which negatively influences their motivation and organisational behaviours (Penc, 2011, p. 145).

Anomie at work emerges as a result of (Kosewski, 2011, p. 46):

- exposing employees to repeated temptations;

- $\quad$ and that way, activating the process of agreeing about excuses within the society;

- creation of a subculture of justified benefits in a group of employees, which offers ready patterns of excuses;

- emergence of personal anomie in employees by way of assuming some or all of the justifications offered by the subculture, which get fixed in their minds.

Anomie at work is an unwritten social agreement based on which it is acceptable to steal from the employer - which means that employees feel that under some particular circumstances, one may steal from a company. However, they do not call themselves thieves, but people who use certain available opportunities. The characteristic feature of anomie is thus a psychological mechanism that allows, e.g., to steal without having a guilty conscience or remorse. The mechanism consists in rationalisation of one's actions based on reinterpretation of pursuits or effects. Reinterpretation of pursuits causes the dimension of the "dignity-benefit" conflict to turn into a safe one, which allows to keep the sense of rightfulness of one's actions and reshape the inner dilemma regarding possible loss of self-esteem (Kosewski, 2008, p. 53). An employee displaying anomic behaviours may come to a conclusion that since a hard time has come, they no longer know what rules should govern their lives (Sarapata, 1993, p. 69; Mansfield, 2004, pp. 88-97) and thus adjust the rules, so that they can pursue their individual interest. Anomie emerges when an employee has no possibility to accomplish the objectives imposed by the society and obtain the socially acceptable 
values with socially legitimate measures consistent with the social norms (Zarycki, 2004, p. 51).

A. Blikle (2017) asserts that anomie may be compared to sepsis (i.e., an extensive infection) that a biological organism may suffer from and treatment of which is long-lasting and costly.

One should seek the sources of anomie in the organisational structure and culture, organisation of work, motivation and management methods, legal rules, in human behaviours and value systems, and in the mechanisms regulating social behaviours in an organisation. When employees witness inconsistencies between the actual behaviour and the values declared by their superiors, they begin to wonder what the acceptable behaviours in an organisation are (Bird \& Waters, 1987; Jensen \& Wygant, 1990; McClelland, 1987). Interest in and the need for teamwork and simultaneous effective leadership increase within organisations (Manderscheid \& Arichvili, 2008). Seeing an appropriate and effective management style, employees will notice their own higher performance and team efficiency. More effective leadership translates into individual effectiveness of team members (Chen \& Lee, 2007; Jung \& Sosik, 2003; Chen \& Bliese, 2002; Katz-Navon \& Erez, 2005). Some studies confirm that by treating an employee as a partner and an individual human being and thus addressing their need for dignity and respect as well as giving them the sense of agency and purposefulness of their actions, it is possible to make them more closely identify with the company (Sypniewska, 2016), and thereby reduce the risk of anomie.

Undoubtedly, one of the most important sources of anomie is mismanagement by the managerial staff that set the example that rules can be broken and values disregarded. On the other hand, being excessively strict with employees pushes them towards rebellion and retreat from the values they hold and towards choosing their own interest.

\section{TEMPTATION - CHOOSING VALUES OR BENEFITS}

Temptation emerges when there is conflict between the motive of seeking one's own benefit and the motive of seeking dignity. Inner conflict occurs when the need for benefits is more important than the need for dignity. If a person is unable to reconcile one motive with the 
other, they are faced with what M. Kosewski refers to as temptation. This is an "either-or" situation; either a person follows a value they believe in or choose personal benefit. The choice affects the person's image of oneself and self-esteem (Kosewski, 2008, p. 20).

Temptation differs from other situations because the underlying motive can be simplified to the choice between the motive of benefit and dignity (or value). A person chooses to benefit at the expense of their morality, whereas by choosing to behave consistently with the values they cherish, they lose the benefit. Temptation causes discomfort and inner tension, which people try to reduce by all means. Within the framework of anomie, reduction of the tension referred to as the dignity dissonance takes place by means of creating reasonable justifications that assuage guilt of doing something against one's beliefs or values.

\section{DIGNITY DISSONANCE AND THE PROCESS OF CREATING EXCUSES}

A person who strives to obtain benefit and pursue a value may encounter temptation in their way, which forces them to choose between one or the other. Choosing to benefit at the expense of one's values results in a feeling of psychological discomfort that people try to assuage by way of agreeing on justifications within the society in order to recover the value that has been lost. According to A. Blikle (2017), each person is biologically endowed with a sense of dignity based on values. If a person gives up those values, they must justify it somehow since there is no person who would claim they are fundamentally evil and unworthy. The phenomenon of dignity dissonance causes tension and discomfort and a person mightily strives to reduce it. If temptations reoccur in a team of employees while the company continues to provide pretexts for agreeing on excuses within the society (such as undignified, unfriendly, or dishonest behaviours towards clients), then according to A. Blikle and M. Kosewski, employee anomie will emerge. Whereas, people who do not accept the excuses that the society has agreed upon get isolated and considered disloyal and in effect suffer from social ostracism. M. Kosewski claims that people who do not undergo the process of agreeing upon excuses within the society, are called losers and the phenomenon - the loser syndrome. If a person is affected by the dignity dissonance but wishes to maintain their self-esteem and 
take pride in themselves, they must have some reasonable justifications for their actions. Reduction of the dissonance is intended to keep up the person's own opinion about themselves as a good, intelligent, and worthy human being. Inner rationalisations are effective only to the point of reaching the threshold of internal tolerance which can shatter easily and then anxiety reappears.

Thus justifications take their credibility from two sources: inner reinterpretation of behaviours and the process of agreeing upon excuses within the society. The latter is the strongest means of legitimisation of an immoral act. Social justifications draw on the influence of the group on an individual and are credible enough to reduce the dignity dissonance. Employees that face temptations agree upon excuses together and choose the ones that are able to ensure their conscience is clear. The group supports them in choosing to benefit and provides understanding of this choice. With social acceptance of an unethical choice that is devoid of values, they feel fair, which allows them to reduce the dignity dissonance effectively (Kosewski, 2008).

\section{RESEARCH METHODOLOGY}

In the first quarter of 2017, a questionnaire-based quantitative study was carried out with the use of survey questionnaires on a group of 1,027 people. The respondents were selected by way of purposive sampling. The selection criterion was employment in a company operating in Poland, regardless of size. Self-employed persons were excluded from the study.

The objective of the study was to identify anomic behaviours as well as excuses for such inappropriate and unethical conduct. The study simultaneously served to verify a thesis that work anomie is present in organisations regardless of the type of company activity, capital, and size, but it is dependent on gender, age, education, form of employment, and position. The following questions were formulated in the course of research:

1. What anomic behaviours manifest themselves in organisations?

2. What excuses are used by people affected by anomie?

3. What is the correlation between anomie at work and the type of business activity, capital, and company size? 
4. What is the correlation between anomic behaviours as well as excuses for such behaviours and gender, age, education, form of employment, and position?

In order to identify anomic behaviours, the respondents were asked whether it happens that without prior consultation with the superior they: leave work early or during work; take stationery away with them when leaving work; photocopy or print private materials; use the Internet for private purposes (such as check social networking websites or other websites, do bank transfers, check a private mailbox, do online shopping, etc.); accept gifts from clients; disclose information, e.g., databases; get company invoices for private purchases; take things intended for the clients; or perform tasks inconsistent with their competences. The respondents could indicate any number of responses from the above multiple-choice answers.

Whereas for the purpose of learning about the structure of excuses for anomic behaviours, the respondents were asked what were their justifications for the above behaviours. Likewise, it was possible to provide any number of responses. The multiple-choice answers comprised the following excuses: they don't pay me enough, so I have to make it even; for my better work they won't pay me more anyway; my family has to live somehow; nobody loses anything because of that; nobody will get poorer; it costs nothing; it didn't happen to a poor one - they can afford it; I do it for clients' sake; only a fool would miss such an opportunity; other people do worse things; my honesty will save no one; I'd rather keep my head down in the group; I have a stupid boss; they do not appreciate me enough.

The responses were provided by 1,027 people, including 666 women $(64.8 \%)$ and 361 men (35.2\%). There were 654 people $(64.7 \%)$ aged between 20 and 29,222 people (21.6\%) aged $30-39,113$ people (11.0\%) aged $40-49$, and 25 people $(2.4 \%)$ aged $50-60$. Three people in the group $(0.3 \%)$ were over 60 years old. Five hundred and twenty-eight respondents (51.4\%) had higher education. Four hundred and ninety-nine people (48.6\%) had secondary education. Two hundred and two people (19.7\%) held a managerial position, 314 people $(30.6 \%)$ held an expert position, 94 people (9.2\%) were blue collar workers, 292 people $(28.4 \%)$ - white collar workers, 84 people (8.2\%) were traders, and $41(4.0 \%)$ held other positions. Two hundred and fourteen people (20.8\%) had been employed for a period of time shorter than a year. Three hundred and ninety-three people (38.3\%) had been employed 
for 1 to 3 years, 234 people (22.8\%) - between 3 and 5 years, 98 people $(9.5 \%)$ - between 5 and 10 years, and 88 people for over 10 year. Five hundred and three people (49.0\%) had an employment contract for an indefinite period of time, 321 people (31.3\%) had a fixed-term employment contract, 129 people (12.6\%) had a contract for specific work, 6 people $(0.6 \%)$ - a contract for specific task, 43 people $(4.2 \%)$ were self-employed, and 25 people (2.4\%) were employed on different terms. Four hundred and sixteen people (40.5\%) worked in service companies, 98 people (9.5\%) - in manufacturing companies, 225 people $(21.9 \%)$ - in trading companies, 169 people (16.5\%) - in mixed companies, and 119 (11.6\%) - in other. Six hundred and seventy-six people $(65.8 \%)$ worked in companies with Polish capital, 227 people $(22.1 \%)$ - in companies with foreign capital, and 124 people $(12.1 \%)$ - in companies with mixed capital. One hundred and forty-three respondents (13.9\%) worked in companies employing up to 9 people, 271 respondents $(26.4 \%)$ - in companies employing between 10 and 49 people, 233 respondents (22.7\%) - in companies employing between 50 and 249 people, and 380 respondents $(37.0 \%)$ - in companies employing at least 250 people. One hundred and two respondents $(9.9 \%)$ worked in state-owned companies, 77 people (7.5\%) - in public administration, 402 people (39.1\%) - in limited liability companies, 209 people $(20.4 \%)$ - in shareholding companies, 146 people (14.2\%) were running their own business, 73 people (7.1\%) worked in international corporations, and 32 people (3.1\%) - in companies that were different legal entities.

\section{RESEARCH RESULTS}

\section{Plan of statistical analysis}

The results obtained from questions concerning behaviours underwent a hierarchical cluster analysis. The algorithm of cluster analysis combined the behaviours that co-occurred and then the justifications of behaviours that co-occurred. For the purposes of cluster analysis, the Jaccard index was employed as a measure of similarity. This measure excludes negative matches, i.e. the algorithm of hierarchical cluster analysis created clusters by combining only the behaviours that were simultaneously indicated by the participant in the study and disregarded the behaviours that were simultaneously not indicated 
by the participant. Based on the co-occurrence of behaviours, more general categories of behaviours were singled out and based on the co-occurrence of justifications, more general categories of justifications were singled out. Owing to the use of the Jaccard index, the analysis combined the elements that co-occur. So groups of co-occurring behaviours were formed. An analogous analysis was carried out with respect to justifications of the respondents' conduct. The second stage of the analysis consisted in studying the correlations among the obtained categories of behaviour and the obtained categories of justifications. Statistical significance was verified with the use of the Pearson's test of independence $\chi^{2}$.

\section{Anomic behaviours and justifications/excuses for these behaviours}

The first method adopted to analyse survey results was standard frequency distribution that served to find out what was the distribution of answers concerning anomic behaviours and internal excuses that the respondents used for these behaviours. Table 1 presents frequency distributions of individual behaviours and excuses.

As Table 1 indicates, the respondents' most frequent anomic behaviour was using the Internet for private purposes. This practice is the most commonly cited by employers as one of the problems with managing people. Companies often block employees' access to social networking websites, purchasing online, and private mailboxes, etc. The study confirmed the scale of this phenomenon. Another most commonly indicated behaviour is photocopying or printing private stuff. In this case, it is also common to hear that in order to avoid such situations, employers use passwords that are intended to allow control of who copied or printed something and how many pages. Leaving work earlier or during working time are also widespread phenomena. In organisations that have no in and out checking equipment in place, employees eagerly yield to temptation, if it is placed in their way. Another anomic behaviour indicated by the respondents is accepting gifts from clients, which may pose a threat in a situation where the person accepting the gift should show gratitude in the future by, e.g., doing something for the giver faster. This situation borders on corruption. The response "take stationery away with oneself when leaving work" is also commonly indicated by the respondents. It is said that the largest 
amount of stationary disappears from companies at the beginning of the school year. The least indications were offered for disclosing information, e.g. databases, however, this behaviour might result in legal consequences since it is stealing the company's property that is subject to professional secret protection. It is likely that employees do not yield to such a temptation in fear of criminal consequences.

Table 1. Frequency distribution - anomic behaviours and excuses

\begin{tabular}{|c|c|c|c|c|c|}
\hline Behaviours & $\mathrm{n}$ & $\%$ & Excuses & $\mathrm{n}$ & $\%$ \\
\hline $\begin{array}{l}\text { Leave work early or during } \\
\text { work }\end{array}$ & 440 & 42.8 & $\begin{array}{l}\text { They don't pay me enough } \\
\text { so I have to make it even }\end{array}$ & 84 & 8.2 \\
\hline $\begin{array}{l}\text { Take stationery away with } \\
\text { oneself when leaving work }\end{array}$ & 218 & 21.2 & $\begin{array}{l}\text { For my better work } \\
\text { they won't pay me more } \\
\text { anyway }\end{array}$ & 81 & 7.9 \\
\hline $\begin{array}{l}\text { Photocopy or print private } \\
\text { materials }\end{array}$ & 638 & 62.1 & $\begin{array}{l}\text { My family has to live } \\
\text { somehow }\end{array}$ & 14 & 1.4 \\
\hline $\begin{array}{l}\text { Use the Internet for private } \\
\text { purposes, such as check social } \\
\text { networking websites or other } \\
\text { websites, do bank transfers, } \\
\text { check the private mailbox, do } \\
\text { online shopping, etc. }\end{array}$ & 695 & 67.7 & $\begin{array}{l}\text { Nobody loses anything } \\
\text { because of that }\end{array}$ & 369 & 35.9 \\
\hline \multirow[t]{2}{*}{ Accept gifts from clients } & 264 & 25.7 & Nobody will get poorer & 194 & 18.9 \\
\hline & & & It costs nothing & 154 & 15.2 \\
\hline $\begin{array}{l}\text { Disclose information, e.g., } \\
\text { databases }\end{array}$ & 28 & 2.7 & $\begin{array}{l}\text { It didn't happen to a poor } \\
\text { one - they can afford it }\end{array}$ & 72 & 7.0 \\
\hline $\begin{array}{l}\text { Get company invoices for pri- } \\
\text { vate purchases }\end{array}$ & 41 & 4.0 & I do it for clients' sake & 61 & 5.9 \\
\hline $\begin{array}{l}\text { Take things intended for the } \\
\text { clients }\end{array}$ & 85 & 8.3 & $\begin{array}{l}\text { Only a fool would miss } \\
\text { such an opportunity }\end{array}$ & 40 & 3.9 \\
\hline \multirow[t]{6}{*}{$\begin{array}{l}\text { Perform tasks inconsistent with } \\
\text { ones' competences }\end{array}$} & 190 & 18.5 & $\begin{array}{l}\text { Other people do worse } \\
\text { things }\end{array}$ & 141 & 13.7 \\
\hline & & & $\begin{array}{l}\text { My honesty will save no } \\
\text { one }\end{array}$ & 38 & 3.7 \\
\hline & & & $\begin{array}{l}\text { I'd rather keep my head } \\
\text { down in the group }\end{array}$ & 14 & 1.4 \\
\hline & & & I have a stupid boss & 32 & 3.1 \\
\hline & & & $\begin{array}{l}\text { They do not appreciate me } \\
\text { enough }\end{array}$ & 112 & 10.9 \\
\hline & & & Other excuses & 237 & 23.1 \\
\hline
\end{tabular}

Source: own elaboration based on own study. 
Whereas as far as rationalisation of one's behaviours and creating inner justifications is concerned, the largest number of the respondents indicated the answer: "nobody loses anything because of that". It is a curiously erroneous line of reasoning since the company that employs them is the one who loses because of that; these are its costs. The thinking that "state-owned means nobody's" is rooted in the socialist economy. Other less frequent responses included "nobody will get poorer", "it costs nothing", which are equally burdensome in terms of costs for the company as the previous answer. Indicating the excuse "other people do worse things" is a psychological mechanism that completely eliminates the dissonance, directing the attention away from oneself to others; others are bad and I am good, even though I choose to benefit. Another justification is concerned with improper management and may constitute valuable information for the company. The answer "they do not appreciate me enough" should make the managerial staff think hard. This indication is related to the process of motivating and one should search for anomic behaviours in this area. A. Blikle (2017) and M. Kosewski (2008) highlight that in order to eliminate anomie in an organisation, one should start from looking into the methods of human resources management. If work ethics are to be respected, it is necessary to take multifaceted actions aimed at creation of proper working conditions by way of respectful and individual treatment.

\section{Anomic behaviours}

The results obtained with questions concerning anomic behaviours in companies underwent a hierarchical cluster analysis. The centroid method was adopted and the Jaccard index was employed as the measure of similarity. Figure 1 presents the obtained dendrogram.

The dendrogram shows the course of combining the behaviours into more general categories. First, the behaviours that co-occurred most commonly where combined, i.e. photocopying or printing private materials and using the Internet for private purposes, next accepting gifts from clients was included in the same category as a behaviour co-occurring with the previous two, etc. The criterion for categorising behaviours as co-occurring was the above-mentioned Jaccard index that takes into account the co-occurrences and disregards the cases where the behaviours were not present in the questionnaire of the same person under examination. 


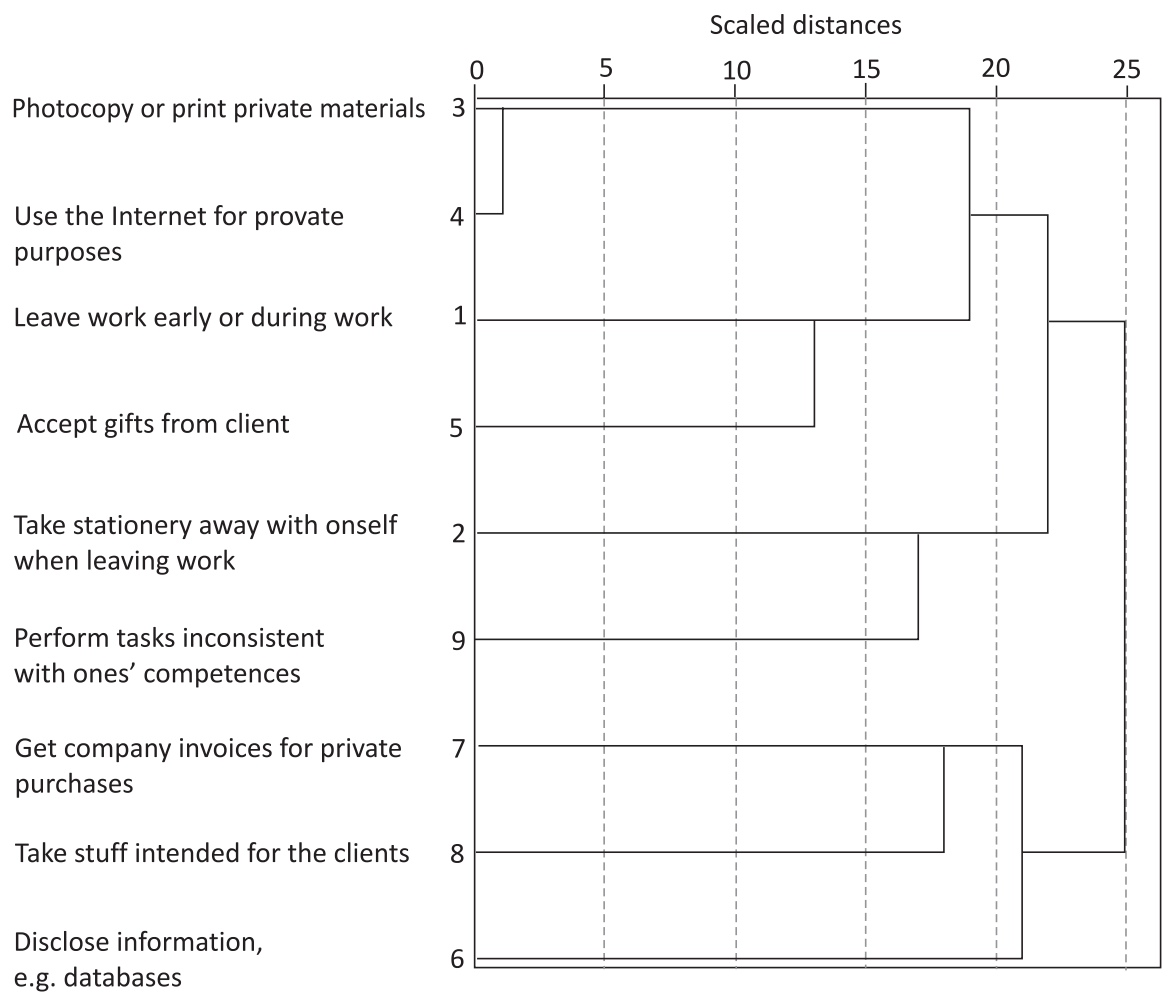

Figure 1. Dendrogram - behaviours displayed in companies Source: own elaboration based on own study.

Finally, following an analysis of co-occurrence of all behaviours, two clusters of anomic behaviours were identified. The first cluster comprised;

- photocopying or printing private materials;

- using the Internet for private purposes;

- leaving work early;

- accepting gifts from clients;

- taking stationery away with oneself when leaving;

- performing tasks inconsistent with one's competences.

The second cluster of anomic behaviours included:

- getting company invoices for private purchases;

- taking things intended for the clients;

- disclosing information, e.g., databases. 


\section{Justifications/excuses for anomic behaviours}

The hierarchical cluster analysis based on the same method was also carried out for the justifications of actions, which the respondents offered. The obtained dendrogram is presented in Figure 2.

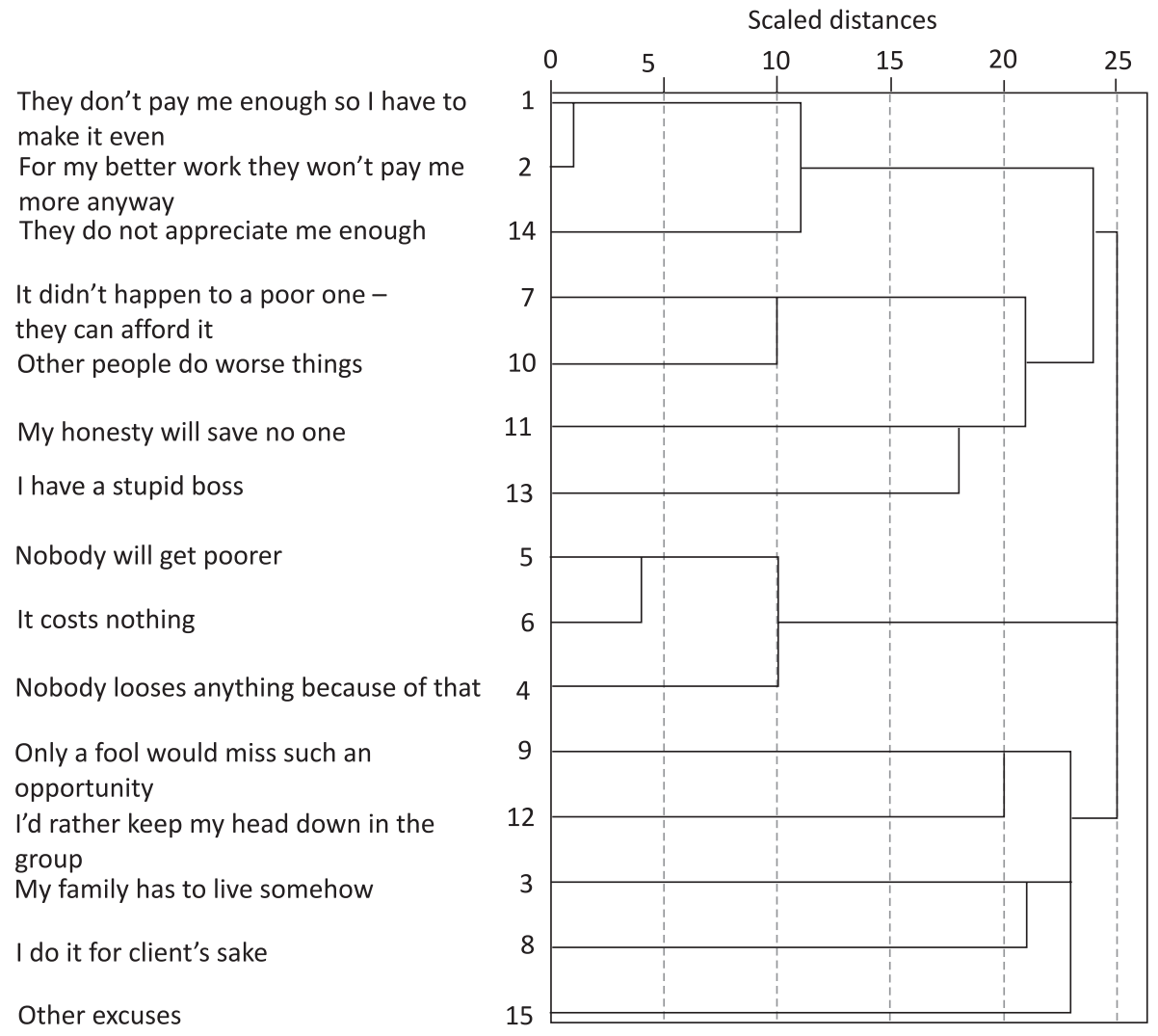

Figure 2. Dendrogram - justifications/excuses for behaviours displayed in companies

Source: own work based on own study.

Finally, following an analysis of co-occurrence of all behaviours, three clusters of justifications/excuses for anomic behaviours were identified. The first cluster comprised the following justifications:

- they don't pay me enough so I have to make it even;

- for my better work they won't pay me more anyway;

- they do not appreciate me enough;

- it didn't happen to a poor one - they can afford it; 
- $\quad$ other people do worse things;

- my honesty will save no one;

- I have a stupid boss.

The second cluster of justifications included:

- nobody will get poorer;

- it costs nothing;

- nobody loses anything because of that.

The third cluster of justifications included:

- only a fool would miss such an opportunity;

- I'd rather keep my head down in the group;

- my family has to live somehow;

- I do it for clients' sake.

\section{Anomic behaviours versus justifications/excuses for these behaviours}

The objective of the successive in-depth statistical analysis was to indicate the correlations among anomic behaviours and the reasons the respondents offered as justifications for such behaviours.

First, the relationships among anomic behaviours from cluster No. 1 and justifications from clusters No. 1, 2, and 3 were verified. Table 2 demonstrates the co-occurrence of individual groups of justifications from the three clusters with anomic behaviours from cluster No. 1. The juxtaposition was supplemented with the results of the Pearson's test $\chi^{2}$.

Table 2. Co-occurrence of individual groups of justifications from the three clusters with anomic behaviours from cluster No. 1

\begin{tabular}{|l|c|c|c|c|c|c|c|}
\hline & \multicolumn{5}{|c|}{ Behaviours cluster No. 1 } & & \\
\hline & no & & yes & & & & \\
\hline Justifications & $\mathrm{n}$ & $\%$ & $\mathrm{n}$ & $\%$ & $x 2$ & $\mathrm{df}$ & $\mathrm{p}$ \\
\hline Cluster No. 1 & 282 & 30.0 & 69 & 50.4 & 22.49 & 1 & 0.001 \\
\hline Cluster No. 2 & 443 & 47.2 & 91 & 66.4 & 17.71 & 1 & 0.001 \\
\hline Cluster No. 3 & 309 & 32.9 & 48 & 35.0 & 0.24 & 1 & 0.621 \\
\hline
\end{tabular}

$\chi^{2}$ - test result; $\mathrm{df}$ - degrees of freedom; $\mathrm{p}$ - statistical significance

Source: own elaboration based on own study. 
It was found that the anomic behaviours from cluster No. 1 co-occurred with the justifications from clusters No. 1 and 2. This means that people who - without prior agreement from or consultation with the superior - admitted that they photocopy or print private materials, use the Internet for private purposes, leave work early, accept gifts from clients, take stationery away with them when leaving work or perform tasks inconsistent with their competences justified their actions by claiming that they do it because: "they don't pay me enough so I have to make it even", "for my better work they won't pay me more anyway", "they do not appreciate me enough", "it didn't happen to a poor one - they can afford it", "other people do worse things", "my honesty will save no one", and "I have a stupid boss". They also indicated the following excuses for anomic behaviours: "nobody will get poorer", "it costs nothing", and "nobody loses anything because of that".

Secondly, the correlations among anomic behaviours from cluster No. 2 and justifications for such actions from clusters No. 1, 2, and 3 were verified.

Table 3 shows the co-occurrence of individual groups of justifications from the three clusters with anomic behaviours from cluster No. 2 . The juxtaposition was supplemented with the results of the Pearson's test $\chi^{2}$.

Table 3. Co-occurrence of individual groups of justifications from the three clusters with anomic behaviours from cluster No. 2

\begin{tabular}{|l|c|c|c|c|c|c|c|}
\hline & \multicolumn{5}{|c|}{ Behaviours cluster No. 2 } & & \\
\hline & no & & yes & & & & \\
\hline Justifications & $\mathrm{n}$ & $\%$ & $\mathrm{n}$ & $\%$ & $x^{2}$ & $\mathrm{df}$ & $\mathrm{p}$ \\
\hline Cluster No. 1 & 4 & 3.2 & 347 & 36.4 & 124.95 & 1 & 0.001 \\
\hline Cluster No. 2 & 3 & 2.4 & 531 & 55.8 & 55.1 & 1 & 0.001 \\
\hline Cluster No. 3 & 1 & 0.8 & 356 & 37.4 & 66.25 & 1 & 0.001 \\
\hline
\end{tabular}

$\chi^{2}$ - test result; $\mathrm{df}$ - degrees of freedom; $\mathrm{p}$ - statistical significance

Source: own elaboration based on own study.

It was found that the anomic behaviours from cluster No. 2 co-occurred with the justifications from clusters No. 1, 2, and 3. This means that people who - without prior agreement from or consultation with the superior - admitted they get company invoices for 
private purchases, take stuff intended for the clients, and disclose information, e.g., databases justified their action by claiming that they do it because: "they don't pay me enough so I have to make it even", "for my better work they won't pay me more anyway", "they do not appreciate me enough", "it didn't happen to a poor one - they can afford it". What is more, the respondents justified their behaviours by saying that "other people do worse things", "my honesty will save no one", "I have a stupid boss", "nobody will get poorer", "it costs nothing", "nobody loses anything because of that", "only a fool would miss such an opportunity", "I'd rather keep my head down in the group", "my family has to live somehow", and "I do it for clients' sake".

Subsequently, the frequency distribution of the above relationships consisting in co-occurrence of anomic behaviours from clusters No. 1 and 2 with the respondents' justifications of their actions in the obtained clusters underwent analysis. Figure 3 shows the frequency distribution of co-occurrence of anomic behaviours from clusters No. 1 and 2 with the justifications from clusters No. 1, 2, and 3.

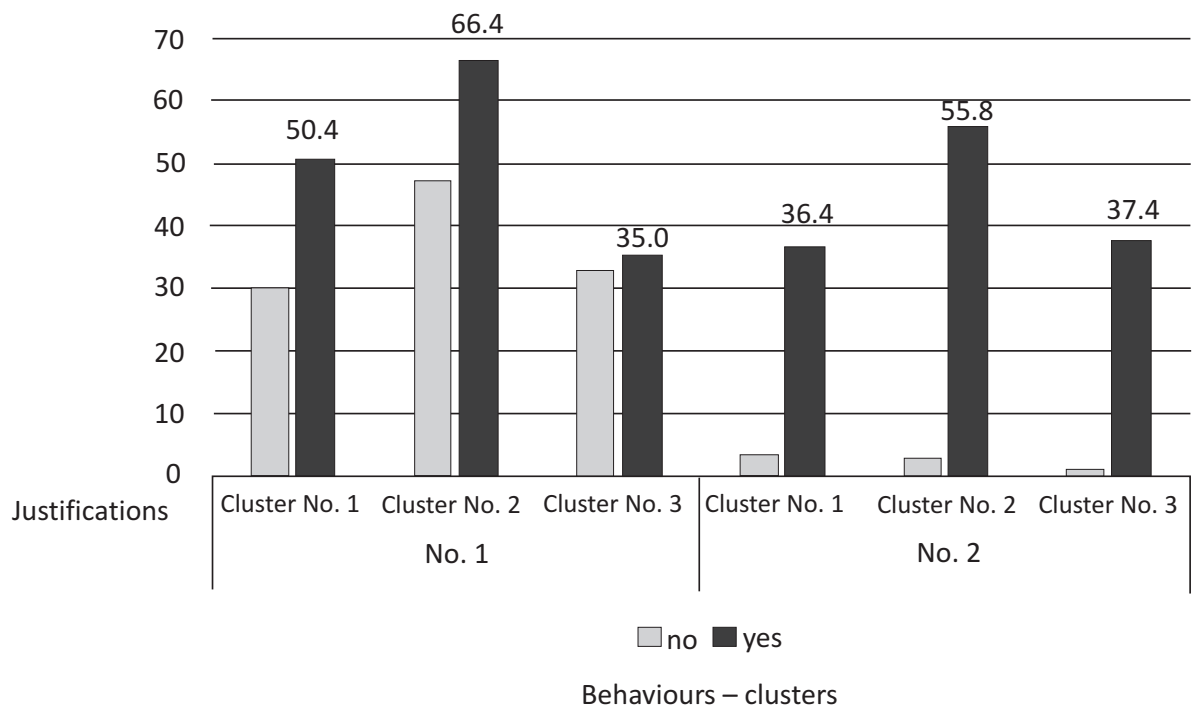

Figure 3. Percentage frequency distribution - co-occurrence of anomic behaviours from clusters No. 1 and 2 with the justifications from clusters No. 1, 2, and 3

Source: own elaboration based on own study . 
In the majority of cases, behaviours from cluster 1, that is, photocopying or printing private materials, using the Internet for private purposes, leaving work early, accepting gifts from clients, taking stationery away with oneself when leaving work, and performing tasks inconsistent with ones' competences co-occurred with justifications from cluster No. 1, that is, they don't pay me enough so I have to make it even, for my better work they won't pay me more anyway, they do not appreciate me enough, it didn't happen to a poor one they can afford it, other people do worse things, my honesty will save no one, and I have a stupid boss as well as with justifications from cluster No. 2, that is, nobody will get poorer, it costs nothing, and nobody loses anything because of that. Behaviours from cluster 2, that is, getting company invoices for private purchases, taking stuff intended for the clients, and disclosing information, e.g., databases predominantly co-occurred with justifications from cluster No. 2, that is, nobody will get poorer, it costs nothing, and nobody loses anything because of that.

\section{Description of the clusters of anomic behaviours and justifications/excuses for such behaviours}

The correlations among displaying anomic behaviours as well as justifications of these behaviours grouped in clusters and the other variables were analysed with the Pearson's test of independence $\chi^{2}$. The remaining variables were: gender, age, education, position, form of employment, type of company activity, capital, and size. It was intended to characterise the individual clusters in terms of the above variables.

\section{The respondents' gender versus anomic behaviours and justifications / excuses for such behaviours}

It was discovered that anomic behaviours from cluster No. 1 are more common in the group of men than in the group of women, $\chi^{2}(1)=16.85, p<0.001$, justifications from cluster No. 1 are more common in the group of men than in the group of women $\chi^{2}(1)=3.95$, $\mathrm{p}<0.05$, and justifications from cluster No. 2 are more common in the group of men than in the group of women $\chi^{2}(1)=4.39, p<0.05$ (see Figure 4). 


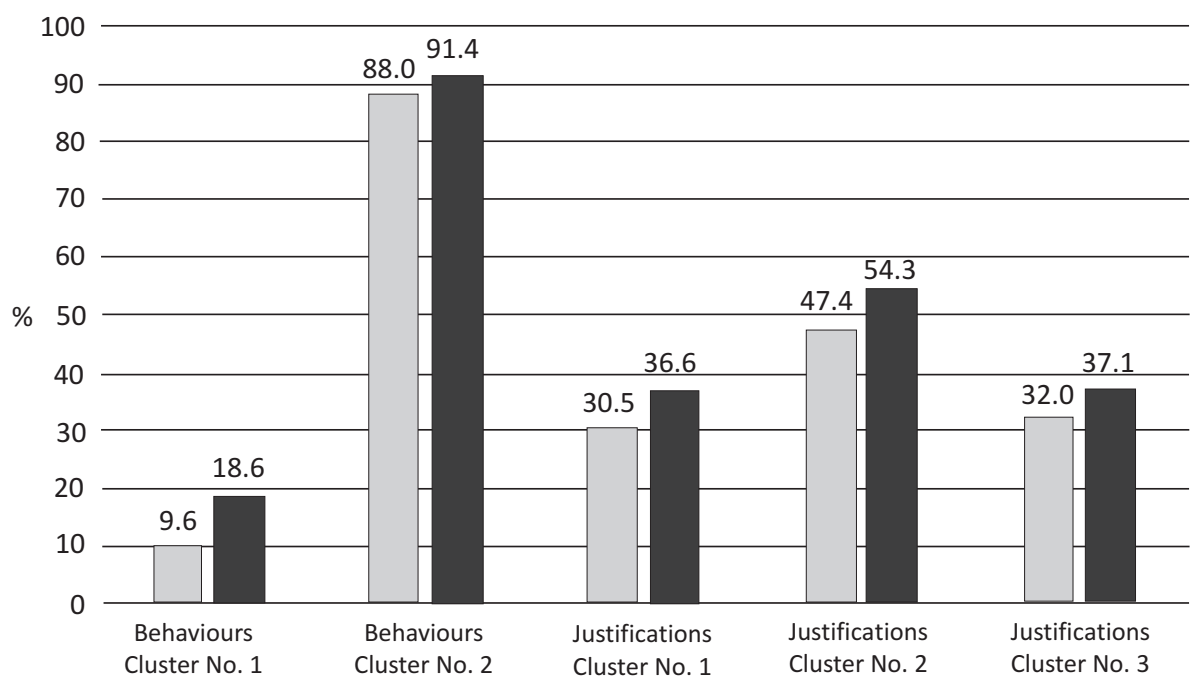

$\square$ women $\square$ men

Figure 4. Percentage frequency distribution - behaviours and justifications of these behaviours according to the respondent's gender Source: own elaboration based on own study .

No significant statistical correlation was found between the respondents' gender and occurrence of anomic behaviours from cluster No. 2, $\chi^{2}(1)=2.85, p<0.05$ and justifications from cluster No. $3, \chi^{2}(1)=2.76$, $\mathrm{p}>0.05$.

This means that men more often than women photocopy or print private materials, use the Internet for private purposes, leave work early, accept gifts from clients, take stationery away with them when leaving work, and perform tasks inconsistent with their competences.

In order to justify their actions, they create a network of internal excuses claiming that: "they don't pay me enough so I have to make it even", "for my better work they won't pay me more anyway", "they do not appreciate me enough", "it didn't happen to a poor one - they can afford it", "other people do worse things", "my honesty will save no one", and "I have a stupid boss". They also reason that nobody will get poorer, it costs nothing or nobody loses anything because of that. 


\section{The respondents' age versus anomic behaviours and justifications/ excuses for such behaviours}

It was discovered that anomic behaviours from cluster No. 1 are less common in the group of the oldest respondents, $\chi^{2}(2)=9.81, p<0.01$ and that justifications from cluster No. 1 are the least common in the group of the oldest respondents $\chi^{2}(2)=17.87, \mathrm{p}<0.001$ (see Figure 5).

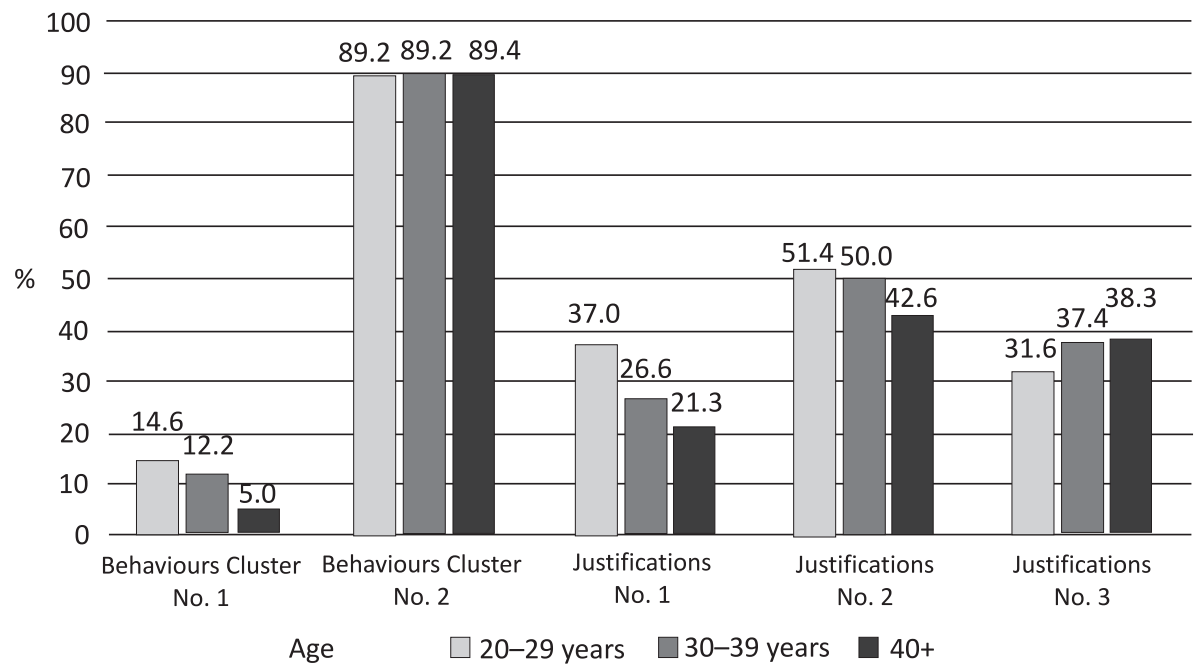

Figure 5. Percentage frequency distribution - behaviours and justifications of these behaviours according to the respondent's age

Source: own elaboration based on own study .

However, no significant statistical correlation was found between the respondents' age and occurrence of anomic behaviours from cluster No. $2 \chi^{2}(2)=0.01, p>0.05$, justifications from cluster No. $2 \chi^{2}(2)=3.61$, $\mathrm{p}>0.05$, or justifications from cluster No. $3 \chi^{2}(2)=3.95, \mathrm{p}>0.05$.

This means that the oldest people (of age 40 or more) rarely photocopy or print private materials, use the Internet for private purposes, leave work early, accept gifts from clients, take stationery away with them when leaving work, or perform tasks inconsistent with their competences. Even if they do display anomic behaviours, they do not create a network of inner excuses that justify their actions in various ways. M. Kosewski (2008) links anomic behaviours to the period when the former model of the state-controlled economy was in place, that is, to the socialist economy with "no owner". He calls this period "anomia 
sovietica". At that time ownership was underdefined, everything was so-called state-owned. In that period anomic behaviours were epidemic; every one could make some "deals" with others and have clear conscience. There was no need for internal justification. Work offered a possibility to make money on the side in governmental positions. It may thus be said that people who grew up in that period might be tainted with this way of thinking. The presented study, however, points out that the oldest employees do not display anomic behaviours and do not feel the need to create justifications. Thus these findings to some extent contradict the claim that anomic behaviours are mainly exhibited by the elderly.

\section{The respondents' education versus anomic behaviours and justifications/excuses for such behaviours}

People with secondary education showed anomic behaviours from cluster No. 2 statistically significantly less frequently $\chi^{2}(1)=13.20$, $\mathrm{p}<0.001$ (see Figure 6).

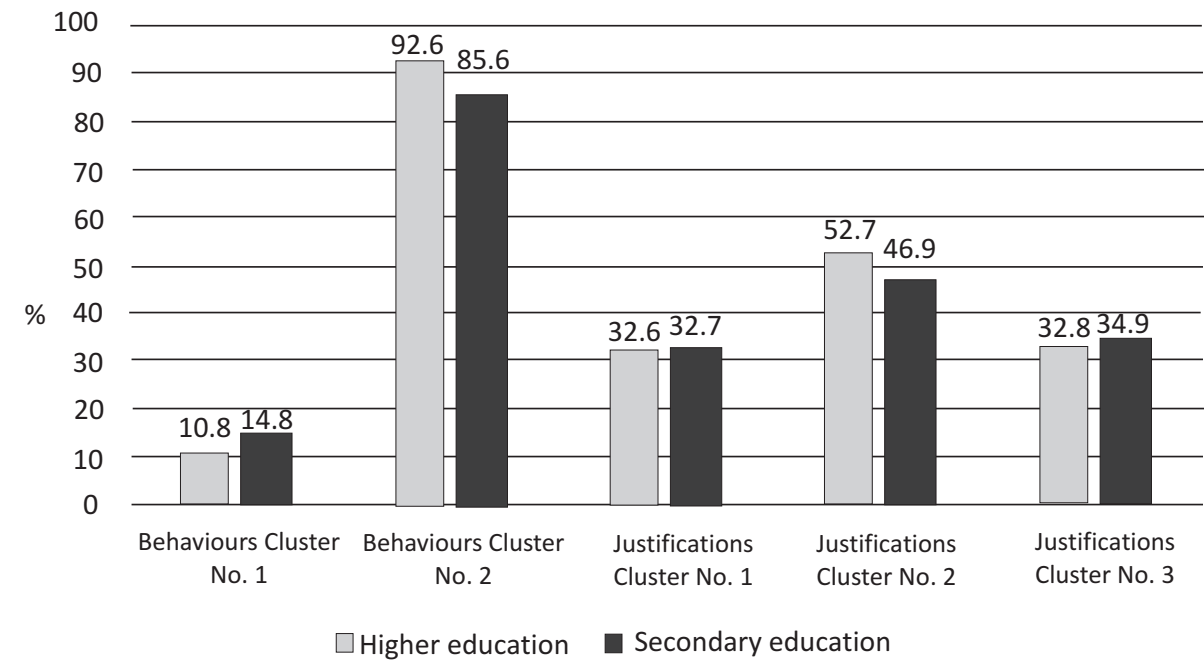

Figure 6. Percentage frequency distribution - behaviours and justifications of these behaviours according to the respondent's education

Source: own elaboration based on own study .

However, no significant statistical correlation was found between the respondents' education and occurrence of anomic behaviours from cluster No. $1 \chi^{2}(1)=3.75, p>0.05$, justifications from cluster 
No. $1, \chi^{2}(1)=0.01, p>0.05$, justifications from cluster No. $2 \chi^{2}(1)$ $=3.40, \mathrm{p}>0.05$, and justifications from cluster No. $3 \chi^{2}(1)=0.51$, $\mathrm{p}>0.05$.

This means that anomic behaviours and justifications are not related to education. There is solely interdependence observable between secondary education and anomic behaviours from cluster No. 2, that is, the respondents with secondary education get company invoices for private purchases, take stuff intended for the clients, and disclose information, e.g., databases, less frequently than the respondents with higher education.

\section{The respondents' position versus anomic behaviours and justifications/ excuses for such behaviours}

Anomic behaviours form cluster No. 2 are more common among people holding managerial and expert positions than among employees $\chi^{2}(2)=12.86, p<0.01$ and justifications from cluster No. 3 are more common among people holding managerial and expert positions than among employees $\chi^{2}(2)=7.53, p<0.05$ (see Figure 7). It is appropriate to mention that for the purposes of statistical analysis blue and white-collar workers as well as traders were classified as employees.

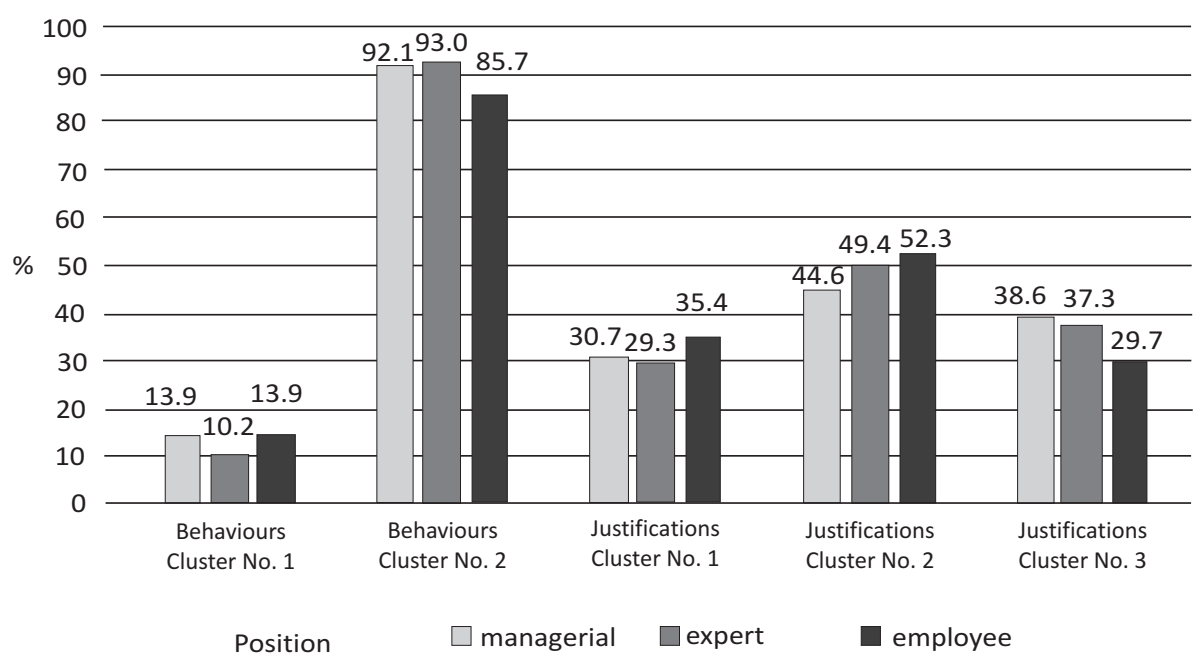

Figure 7. Percentage frequency distribution - behaviours and justifications of these behaviours according to the respondent's position

Source: own elaboration based on own study . 
However, no significant statistical correlation was found between the respondents' position and occurrence of anomic behaviours from cluster No. $1 \chi^{2}(2)=2.67, p>0.05$, justifications from cluster No. $1 \chi^{2}(2)=3.74$, $\mathrm{p}>0.05$ or justifications from cluster No. $2 \chi^{2}(2)=3.47, \mathrm{p}>0.05$.

The above findings are surprising and frightening. According to M. Kosewski (2008), managerial positions should be free from anomie since people who hold such positions set the example. Hence if employees see anomic behaviours among their superiors or if bad management is practised in an organisation, one should hardly expect that these employees will not seize opportunities and yield to "good temptations" placed in their way. A manager should set an ethical example with their behaviour and show that if temptation arises, one should choose the good of the company instead of one's own. Employees seeing their superiors will not directly copy their behaviours, but they will use it as examples for creating credible justifications. Thus if one wishes to eradicate anomic behaviours occurring among employees, one should first eliminate anomie and justifications among the managerial staff.

\section{The respondents' form of employment versus anomic behaviours and justifications/excuses for such behaviours}

People having an employment contract for an indefinite period of time indicated anomic behaviours from cluster No. 2 more often than people having fixed-term employment contracts and contracts for specific work $\chi^{2}(2)=17.60, \mathrm{p}<0.001$ (see Figure 8 ).

However, no significant statistical correlation was found between the respondents' form of employment and occurrence of anomic behaviours from cluster No. $1^{2}(2)=0.30, p>0.05$, justifications from cluster No. $1, \chi^{2}(2)=1.79, p>0.05$, justifications from cluster No. $2 \chi^{2}(2)=1.09$, $\mathrm{p}>0.05$, and justifications from cluster No. $3 \chi^{2}(2)=3.13, \mathrm{p}>0.05$.

The above result is not surprising. People having fixed-term contracts or contracts per specific work or task protect their future and hope to be constantly employed by an organisation and thus avoid behaviours that might be considered satisfactory grounds for dismissal. This result also means that people having employment contracts for an indefinite period of time will get company invoices for private purchases, take things intended for the clients, and disclose information, e.g., databases, more frequently than people having fixed-term contracts or contracts per specific work or task. 


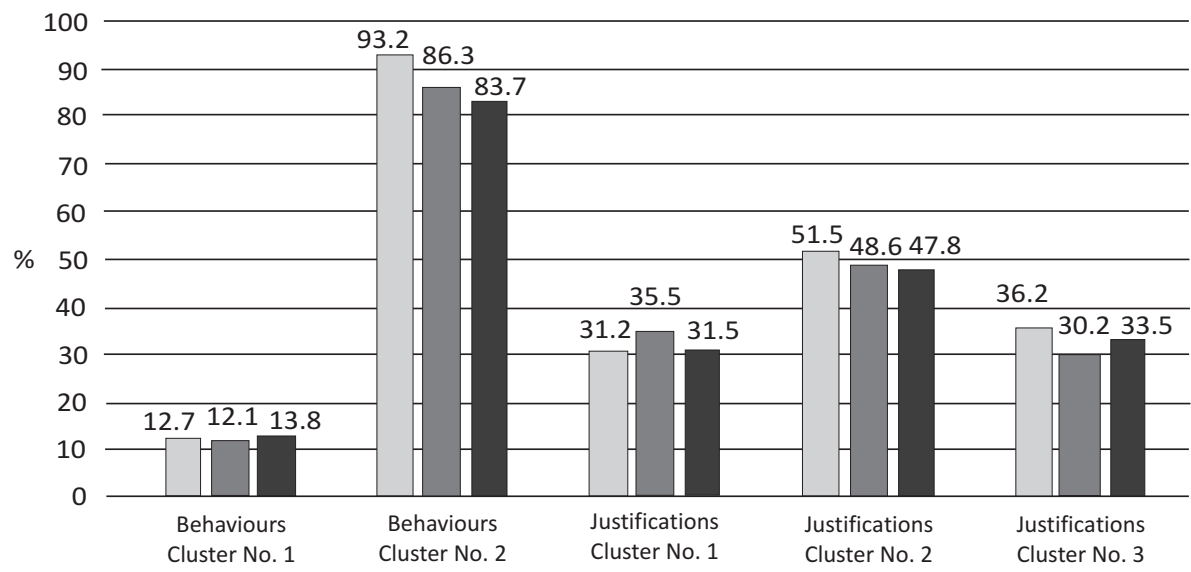

Contract $\square$ for an indefinite period of time

$\square$ fixed-tem employment

for specific work

Figure 8. Percentage frequency distribution - behaviours and justifications of these behaviours according to the respondent's form of employment Source: own elaboration based on own study .

Type of company activity, capital, and size versus anomic behaviours and justifications/excuses for such behaviours

No significant statistical correlation was found between the type of company activity and occurrence of anomic behaviours from cluster No. $1 \chi^{2}(4)=5.86, p>0.05$, anomic behaviours from cluster No. 2 $\chi^{2}(4)=4.20, p>0.05$, justifications from cluster No. $1, \chi^{2}(4)=0.55$, $p>0.05$, justifications from cluster No. $2, \chi^{2}(4)=4.66, p>0.05$, and justifications from cluster No. $3, \chi^{2}(4)=3.87, p>0.05$.

Moreover, no significant statistical correlation was found between type of capital of the company and occurrence of anomic behaviours from cluster No. $1 \chi^{2}(2)=1.36, p>0.05$, anomic behaviours from cluster No. $2, \chi^{2}(2)=0.13, \mathrm{p}>0.05$, justifications from cluster No. 1 , $\chi^{2}(2)=0.47, \mathrm{p}>0.05$, justifications from cluster No. $2, \chi^{2}(2)=2.09$, $\mathrm{p}>0.05$, and justifications from cluster No. $3, \chi^{2}(2)=0.06, \mathrm{p}>0.05$.

No significant statistical correlation was discovered between company size and occurrence of anomic behaviours from cluster No. $1^{2}(3)=6.64$, $p>0.05$, anomic behaviours from cluster No. $2 \chi^{2}(3)=6.33, p>0.05$, justifications from cluster No. $1 \chi^{2}(3)=1.88, \mathrm{p}>0.05$, justifications from cluster No. $2 \chi^{2}(3)=2.16, p>0.05$, and justifications from cluster No. $3 \chi^{2}(3)=1.06, \mathrm{p}>0.05$. 
The above findings indicate that anomic behaviours or creation of justifications occur regardless of the type of company activity, capital, or size.

\section{CONCLUSIONS}

Based on the study, it may be claimed that:

- Anomie at work is present in organisations in the form of different anomic behaviours depending on the type of temptation.

- Justifications for anomic behaviours, which serve as a basis for inner reinterpretation, are varied.

- The most common anomic behaviours are: using the Internet for private purposes, photocopying or printing private materials, leaving work early or during work, taking stationery away with oneself when leaving work, and accepting gifts from clients.

- The most common excuses for anomic behaviours are: nobody loses anything because of that, nobody will get poorer, it costs nothing, other people do worse things, and they do not appreciate me enough.

- Men more often than women photocopy or print private materials, use the Internet for private purposes, leave work early or during work, accept gifts from clients, and take stationery away with them when leaving work.

- To justify their actions, men create a network of inner excuses claiming that: "they don't pay me enough so I have to make it even", "for my better work they won't pay me more anyway", "they do not appreciate me enough", "it didn't happen to a poor one - they can afford it", "other people do worse things", "my honesty will save no one", and "I have a stupid boss". They also reason that nobody will get poorer, it costs nothing or nobody loses anything because of that.

- Older people (of age 40 or more) less frequently than young people photocopy or print private materials, use the Internet for private purposes, leave work early, accept gifts from clients, take stationery away with them when leaving work, and perform tasks inconsistent with their competences.

- Even if older people (of age 40 or more) display anomic behaviours, they do not create a network of inner excuses. 
- Generally, anomic behaviours and justifications are not dependent on education, however, the respondents with secondary education get company invoices for private purchases, take things intended for the clients, and disclose information, e.g., databases, less frequently than the respondents with higher education.

- Anomic behaviours (such as getting company invoices for private purchases, taking stuff intended for the clients, and disclosing information, e.g., databases) are more common among people holding managerial and expert positions than among blue or white collar workers and traders.

- Justifications for anomic behaviours (only a fool would miss such an opportunity, I'd rather keep my head down in the group, my family has to live somehow, and I do it for clients' sake) are more common among people holding managerial and expert positions than among blue or white collar workers and traders.

- People having employment contracts for an indefinite period of time will get company invoices for private purchases, take stuff intended for the clients, and disclose information, e.g., databases more commonly than people having fixed-term contracts or contracts per specific work or task.

- Anomic behaviours and creating justifications occur regardless of the type of company activity, capital, and size.

\section{REFERENCES}

Baumer, E.P. (2007). Untangling research puzzles in merton's multilevel anomie theory. Theoretical Criminology, 11(1), 63-93.

Bird, F. \& Waters, J. (1987). The nature of managerial moral standards. Journal of Business Ethics, 6, 1-3.

Blikle, A. (2017). Doktryna jakości. Wydanie II Turkusowe [The Doctrine of Quality. Edition 2, Turquoise]. Warszawa: One Press.

Chen, C. \& Lee, H. (2007). Effects of transformational team leadership on collective efficacy and team performance. International Journal of Management and Enterprise Development, 4, 202-217.

Chen, G. \& Bliese, P.D. (2002). The role of different levels of leadership in predicting self- and collective efficacy: Evidence for discontinuity. Journal of Applied Psychology, 87, 549-556. 
Cohen, D.V. (1992a). The Dynamics of Powerlessness: Explaining Unethical Conduct in Business Organizations. Paper presented at the $52^{\text {nd }}$ Annual Meeting of the Academy of Management Las Vegas, NV.

Cohen, D.V. (1992b). Ethical Choice in the Workplace: Situational and Psychological Determinants. Doctoral dissertation. Columbia University, New York, NY.

Durkheim, E. (2000). The Division of Labor in Society. In: A. Hite \& J.T. Roberts (eds.), From Modernization to Globalization: Perspectives on Development and Social Change. Blackwell Publishing, 37-66.

Durkheim, E. (2006). Samobójstwo. Studium socjologii [Suicide. The Sociological Study]. Warszawa: Oficyna Naukowa.

Featherstone, R. \& Deflem, M. (2003). Anomie and strain: context and consequences of merton's two theories. Sociological Inquiry, 73(4), 471-489.

Hatch, M.J. (2002). Teoria organizacji [The Theory of Organization]. Warszawa: Wydawnictwo Naukowe PWN.

Jensen, L. \& Wygant, S. (1990). The development of self-valuing theory: A practical approach for business ethics. Journal of Business Ethics, 8, 215-225.

Jung, D. \& Sosik, J. (2003). Group Potency and Collective Efficacy. Group Organization Management, 28, 366-391.

Katz-Navon, T. \& Erez, M. (2005). When collective and self-efficacy affect team performance. Small Group Research, 36, 437-465.

Kisielnicki, J. (2008). Zarzqdzanie: Jak zarzqdzać i być zarzqdzanym [Management: How to Manage and Be Managed]. Warszawa: PWE.

Kosewski, M. (2008). Wartość, godność i władza [Virtue, Dignity, and Power]. Warszawa: Vizja.

Kosewski, M. (2011). Triada wspótzależności: Jakość - samokontrola - etos pracowniczy. Anomia pracownicza w Polsce 2012. Raport Skala oszustw i kradzieży w firmach, Pracodawcy RP [A Triad of Interrelationships: Quality - Self-Control - Work Ethos. Anomie at work in Poland, 2012. A Report on the Scale of Fraud and Stealing in Companies. Employers in the Republic of Poland].

Manderscheid, S.V. \& Arichvili, A. (2008). New leader assimilation: Process and outcomes. Leadership and Organization Development Journal, 29, 661-677.

Mansfield, P. (2004). Anomie and disaster in corporate culture: The impact of mergers and acquisitions on the ethical climate of market organizations. Marketing Management Journal, 14(2), 88-97.

McClelland, V. (1987). Mixed signals breed mistrust. Personnel Journal, March, 24-27.

McCloskey, D. (1976). Durkheim, anomie, and modern crisis. American Journal of Sociology, 81(6), 1481-1487. 
Merton, R.K. (1938). Social structure and anomie. American Sociological Review, 3, 672-682.

Merton, R.K. (2002). Teoria socjologiczna i struktura społeczna [Sociological Theory and Social Structure]. Warszawa: Wydawnictwo Naukowe PWN.

Messner, S.F. (2003). An institutional-anomie theory of crime: Continuities and elaborations in the study of social structure and anomie. Cologne Journal of Sociology and Social Psychology, 43, 93-109.

Morgan, G. (1997). Obrazy organizacji [The Images of Organization]. Warszawa: Wydawnictwo Naukowe PWN.

Passas, N. (1990). Anomie and corporate deviance. Contemporary Crises, 14, 157-178.

Penc, J. (2011). Zachowania organizacyjne w przedsiębiorstwie. Kreowanie twórczego nastawienia i aspiracji [Organisational Behaviours in a Company. Steering Creative Approach and Aspirations]. Warszawa: Wolters Kluwer Polska.

Poveda, T.G. (1994). Rethinking White Collar Crime. Westport CT: Prager Publishers. Sarapata, A. (1993). Nowoczesność Polaków: W poszukiwaniu modelu nowoczesnego Polaka [Modernity of the Polish: Searching for the Model of a Modern Pole]. Warszawa: Instytut Kultury.

Stelmach, W. (2009). Wtadza i kierowanie [Power and Management]. Warszawa: Placet. Sudoł, S. (2006). Przedsiębiorstwo [Company]. Warszawa: PWE.

Szacka, B. (2008). Wprowadzenie do socjologii [Introduction to Sociology]. Warszawa: Oficyna Naukowa.

Szafraniec, K. (1986). Anomia-przesilenie tożsamości. Jednostka i społeczeństwo wobec zmiany [Anomie-Solstice of Identity. Individual and the Society in the Face of Change]. Torun: UMK.

Szczepański, J. (1963). Elementarne pojęcia socjologii [Basic Sociological Concepts]. Warszawa: PWN.

Sztompke, P. (2007). Socjologia [Sociology]. Warszawa: Znak.

Sypniewska, B.A. (2016). Godnościowa satysfakcja pracownicza [Employee Dignity-Related Satisfaction]. In: T. Oleksyn \& B.A. Sypniewska (eds.), Zarzqdzanie zasobami ludzkimi. Refleksje teoretyczne, kwestie praktyczne [Human Resources Management. Theoretical Thoughts, Practical Issues]. Warszawa: WSFiZ, 359-374.

Thio, A. (1975). Critical Look at Mertons Anomie Theory. Pacific Sociological Review, 18(21), 139-158.

Turska-Kawa, A. (2010). Psychologiczne uwarunkowania zachowań wyborczych [Psychological Conditioning of Electoral Behaviours]. In: A. Turska-Kawa \& W. Wojtasik (eds.), Preferencje polityczne 2009. Postawy, identyfikacje, zachowania [Political Preferences 2009. Attitudes, Identifications, Behaviours]. Katowice: Unikat 2, 102-107. 
Tyc, W. (2007). Ekonomiczne i społeczne uwarunkowania transformacji rodziny [Economic and Social Conditioning of Family Transformation]. Wrocław: AE.

Vaughan, D. (1983). Controlling Unlawful Organizational Behavior: Social Structure and Corporate Misconduct. Chicago: University of Chicago Press.

Willis, C.L. (1982). Durkheim concept of anomie - some observations. Sociological Inquiry, 52(2), 106-113.

Zahra, S. (1989). Executive values and the ethics of company politics: Some preliminary findings. Journal of Business Ethics, 8, 15-29.

Zarycki, T. (2004). Kapitał społeczny a trzy polskie drogi do nowoczesności [Social Capital Versus Three Polish Paths to Modernity]. Kultura i Społeczeństwo [Culture and Society], 2, 51. 


\section{ANOMIA PRACOWNICZA. PROBLEM I ZAGROŻENIE}

\section{Abstract}

Background. Anomia pracownicza to rodzaj anomii społecznej wpisujący się w działalność zawodowa, kiedy pracownicy narażeni są na ekspozycję powtarzającej się sytuacji pokusy. Wytwarzają wówczas wiarygodne usprawiedliwienia, które zostają utrwalone. Anomia występuje w organizacjach, w których wartości istnieja, są nawet zapisane, ale nie są przestrzegane. Źródeł powstania anomii pracowniczej szukać należy w kulturze organizacyjnej, strukturze organizacyjnej, organizacji pracy, sposobach motywowania i zarządzania, regulacjach prawnych, a także w zachowaniach człowieka i jego systemach wartości, w mechanizmach regulujacych społeczne zachowania człowieka w danej organizacji. Zjawisko anomii pracowniczej wpisane jest w naturę prawie każdego biznesu, ale każde etyczne działanie ją ogranicza. Celem niniejszego artykułu jest analiza problematyki anomii pracowniczej, jej uwarunkowań, przyczyn i metod postępowania.

Research aims. Celem niniejszego artykułu jest analiza problematyki anomii pracowniczej, jej uwarunkowań, przyczyn i metod postępowania, z uwzględnieniem problematyki sytuacji pokusy oraz analizą dysonansu godnościowego i stosowanych wewnętrznych usprawiedliwień czyli uzasadnień niewłaściwego zachowania. W artykule zostana zaprezentowane wyniki badania własnego przeprowadzonego w 2017 roku na grupie 1027 respondentów. Analiza dotyczy identyfikacji zachowań anomijnych i stosowanych dla nich usprawiedliwień czyli uzasadnień niewłaściwego, nieetycznego zachowania. Badanie było jednocześnie próbą weryfikacji tezy, że zjawisko anomii pracowniczej występuje w organizacjach niezależnie od rodzaju działalności firmy, kapitału i wielkości firmy, ale jest zależne od płci, wieku, wykształcenia, formy zatrudnienia oraz stanowiska.

Methodology. W pierwszym kwartale 2017 roku przeprowadzone zostało badanie ilościowe metodą ankietową na podstawie kwestionariusza ankiety w grupie 1027 osób. Dobór osób do badania był celowy. Kryterium doboru było zatrudnienie w przedsiębiorstwie funkcjonującym w Polsce, bez względu na wielkość firmy. $\mathrm{Z}$ badania wyłączone zostały osoby samozatrudnione.

Findings. Na podstawie badania można stwierdzić, że zjawisko anomii pracowniczej występuje w organizacjach, ale różne są zachowania anomijne. Podobnie, występuje różnorodność stosowanych usprawiedliwień, uzasadnień swojego anomijnego zachowania będących podstawą wewnętrznej reinterpretacji. Badanie wykazało, że zjawisko anomii pracowniczej występuje w organizacjach niezależnie od rodzaju działalności firmy, kapitału i wielkości firmy, ale jest zależne od płci, wieku, wykształcenia, formy zatrudnienia oraz stanowiska.

Keywords: anomia pracownicza, sytuacja pokusy, usprawiedliwienia, dysonans godnościowy 